Acta Universitatis Wratislaviensis • No 3869

Literatura i Kultura Popularna XXIV, Wrocław 2018

DOI: $10.19195 / 0867-7441.24 .10$

\author{
Ewa Mazierska \\ ORCID: 0000-0002-4385-8264 \\ University of Central Lancashire, Preston
}

\title{
No longer a trivial entertainment: Popular cinema in Poland after 2000
}

Keywords: Polish cinema, Polish popular cinema, Polish contemporary cinema

Słowa kluczowe: Polskie kino, polskie kino popularne, polskie kino współczesne

To understand the specificity of Polish popular cinema of the last decade and a half, one has to locate it in the postwar history of filmmaking in this country. Accordingly, I begin this chapter by sketching out such a history and then I proceed to discussing two types of Polish popular film of the new millennium: a subgenre of romantic comedy, which I label "sexual comedy", represented by the films of Andrzej Saramonowicz and Tomasz Konecki, and "popular arthouse film", represented by Dzień świra (Day of the Wacko, Poland 2002) by Marek Koterski.

\section{Genre and popular cinema in postwar Poland}

In the Poland of state socialism (1945-1989), cinema produced merely for entertainment, labelled "popular cinema", had a low status. This was due to the fact that official ideology bestowed on filmmakers a responsibility to educate their viewers. Profit was of secondary importance and this was reflected in the specific organization of the film industry, based on semi-independent units (or studios), headed by leading directors and enjoying generous budgets allocated by the state, which did not expect to recuperate its investment. Bonuses were often paid not according to the profit generated by the film, but to its costs, and so the economy of film production and distribution was so complicated, that it was difficult to 
assess whether a given film created a profit or a loss. ${ }^{1}$ Such a situation added to edifying the auteurist paradigm, at the expense of popular cinema, because the artistic quality of the films, measured by favourable reviews and awards received at international festivals was the only reliable measure of their success.

That said, the state also promoted the production of popular films, either as a more effective means of instilling in viewers the right attitudes or helping the financial condition of the Polish film industry. For example, in the early 1960s the Party published a document, which encouraged filmmakers to make films about everyday life, which would be truthful, yet optimistic and praising the socialist status quo. ${ }^{2}$ This directive led to the production of a large number of genre films, especially romantic and criminal comedies, such as Dwa żebra Adama (Adam's Two Ribs, 1963), directed by Janusz Morgenstern, Lekarstwo na miłość (Medicine for Love, 1965) by Jan Batory and Matżeństwo z rozsadku (Marriage of Convenience, 1966), directed by Stanisław Bareja. However, these films were denigrated by the critics. Not only were individual films criticized, but it was argued that structurally the Polish film industry is not fit for the production of popular films. Symptomatic in this respect was the opinion of a leading Polish critic of the 1960s, Bolesław Michałek. He argued that it was impossible to follow the Party's instructions and produce films of high quality, because films true to reality had to be either critical and pessimistic, in the vein of those produced by independent filmmakers from New York in the 1960s, as represented by The Connection (1962) directed by Shirley Clarke ${ }^{3}$ or genre films of the type produced by French directors such as Jacques Becker. ${ }^{4}$

In Michałek's view, Polish cinema had little chance of succeeding in either of these types. The first type was difficult due to censorship constraints; the second due to the lack of an appropriate framework to produce genre films in an industry dominated by the auteurist model..$^{5}$ This argument was subsequently repeated by numerous Polish critics, often without properly assessing the arguably popular films or even watching them. Their assumption was that if a filmmaker attempted to make a genre film, especially such a highly coded movie, as a musical or a science-fiction film, s/he cannot succeed. At the same time, some auteurist films, such as Andrzej Wajda's Popiót i diament (Ashes and Diamonds, 1958), Człowiek z marmuru (Man of Marble, 1977) and Człowiek z żelaza (Man of Iron, 1981)

${ }^{1}$ On the organisation of the Polish film industry see: E. Zajiček, Poza ekranem. Kinematografia Polska 1918-1991, Warszawa 1992; M. Adamczak, Globalne Hollywood, filmowa Europa i polskie kino po 1989 roku. Przeobrażenia kultury audiowizualnej przetomu stuleci, Gdańsk 2010.

2 "Uchwała Sekretariatu KC w sprawie kinematografii", [in:] Syndrom konformizmu. Kino polskie lat sześćdziesiatych, eds. T. Miczka, A. Madej, Katowice 1994, pp. 27-34.

${ }^{3}$ B. Michałek, "Wokół polskiego filmu o współczesności", [in:] Bolesław Michałek, ambasador polskiego kina. Wspomnienia i artykuty, ed. A. Helman, Kraków 2002, p. 121.

${ }^{4}$ Ibid., p. 125.

${ }^{5}$ Ibid., p. 126. 
added to the argument that Polish cinema did not need to flatter the audience; in Poland, auteurist cinema fulfils all functions that cinema can and should play.

In the light of the situation sketched out above, it is not surprising that we can identify two principal meanings of "popular cinema" in Poland; one concerns films which tried to be popular by conforming to genre conventions and either being politically conformist or neutral in relation to politics and one which tried to achieve popularity by engaging with problems regarded as very important for the society and typically showing a critical attitude to state socialism. There are filmmakers who bucked these trends, most importantly Juliusz Machulski, whose Vabank (1981) and Seksmisja (Sex Mission, 1984) were genre, popular, politically subversive (or at least read by the audience as being critical of the dominant ideology) and yet praised by the critics. However, it should be emphasized that Machulski started his career in the 1980s, when the Polish film industry was attempting to reform itself by becoming more market-oriented. Although these early attempts at neoliberalisation were at best marginally successful, they instilled in filmmakers and critics the idea that commercial success matters and there is a correlation between the film's adherence to genre and its popularity. Inevitably, Machulski became not only a successful filmmaker throughout the 1980s and subsequent decades, but a source of inspiration (and envy) for the younger generation of Polish filmmakers.

As a result of the privileged position of the arthouse film in Poland, the vast majority of studies of Polish cinema conducted before 2000 are concerned with this type of cinema, while omitting or marginalizing popular cinema. For example, there are probably 20 volumes published in Poland and examining different aspects of the work of Andrzej Wajda, but none devoted to Polish science-fiction films or musicals. If we look at the literature available in English, the situation will be even worse (from the perspective of discussing popular cinema), with auteurist cinema having the almost undivided attention of scholars. Not only are there few studies of Polish genre cinema, but what is also missing is a consideration of the work of famous authors from the perspective of genre, for example locating the work of Andrzej Wajda in a tradition of war film or melodrama or considering reasons why certain auteurist endeavours were hits among Polish and international audiences, while others flopped.

\section{Popular cinema in Poland after the fall of state socialism}

After 1989, the Polish film industry went through a period of reform to become more competitive. This does not mean that the state completely withdrew from supporting film production and film culture. Such support still exists, especially since the setting up of the Polish Film Institute in 2005, and it is in large part 
directed towards subsidizing arthouse cinema. Nevertheless, the subsidy normally covers only half of the production costs and filmmakers who receive it have to demonstrate that their projects have some commercial potential. Turning to genre is an obvious way to achieve this goal, because the most successful films in Poland after 1989 in terms of box office results are genre films, produced in Hollywood, but also in some European countries, such as France. The Polish audience post-1989 is more accustomed to genre cinema than in the previous period and to communicate with it effectively, filmmakers have to use a language their viewers understand.

Privileging certain genres also proved the perfect strategy to reflect the changes Poland has experienced since the fall of state socialism in 1989. The upsurge of gangster films in the first decade after the fall of the Berlin Wall can be explained by the violent transformation of the economy from one planned by the state to a neoliberal one. This change led to creating a new social stratum of "feral capitalists", namely millionaires and billionaires, taking advantage of the privatisation of state assets, and pauperisation of a large proportion of the population, and the sense of injustice resulting from such development. Gangster cinema effectively captures this shift and testifies to the resentment it caused to the victims of neoliberalisation. ${ }^{6}$

The upsurge of heritage cinema ten or so years after the fall of state socialism can be regarded as a way to offer audiences an imaginary escape from the present to a mythologised past, reflecting the nationalistic agenda of the leading parties and the need to find a refuge from the darker sides of everyday reality. ${ }^{7}$ The production of such films was possible not only thanks to generous support from the state, but also due to its distribution being fixed in advance by ensuring that they will be watched by school children (and even soldiers) as part of literary and civic education. ${ }^{8}$ The subsequent decline of gangster cinema, testifies to the fact that economic transformation is more or less finished; neoliberalism in Poland has been taken for granted. In the case of heritage cinema, the main reason for decline was the exhaustion of suitable material, as the majority of novels included in the literary canon have been screened, and the audience tired of watching the same type of film over and over again. Finally, after 2000 we see romantic comedies flourishing as a sign of the normalisation of political and social reality and a greater interest of audiences in private existence. By and large, all these films testify to the utopian potential of popular cinema and popular culture generally. ${ }^{9}$

Since the fall of state socialism, we also observe a growing number of studies concerning popular films, both from the period of state socialism and post-

${ }^{6}$ E. Mazierska, Polish Postcommunist Cinema: From Pavement Level, Oxford 2007, pp. 43-62.

${ }^{7}$ Ibid., pp. 63-89; E. Ostrowska, The Power of Love: Polish Postcommunist Popular Cinema, forthcoming.

${ }^{8}$ E. Mazierska, op. cit., pp. 70-72.

${ }^{9}$ See Dyer on musicals; R. Dyer, Only Entertainment, 2nd ed., London 2002, pp. 19-35. 
communism. ${ }^{10}$ This can be attributed to the increased interest in and prestige of popular cinema globally, which Polish film historians could no longer ignore. Not only are there more studies on this subject, but their tone is different from those produced in the past. Their authors no longer embark on chastizing filmmakers for making poor comedies or melodramas, or at least this is not the main task of their studies, but rather they try to establish what the social functions of such productions are. Moreover, we notice first attempts to examine the work of leading Polish authors from the perspective of genre, such as considering Wajda's acclaimed Katyń as a melodrama. ${ }^{11}$

\section{"Sexual comedies"}

Romantic comedies belong to the most popular genres worldwide, as testified by the fact that they are treated as a separate genre, despite being a hybrid of two genres: comedy and romance. It is not a surprise that we find many romantic comedies among films produced in Poland in the last ten years or so. What is more surprising, is the low proportion of films of this type in the 1990s. The reason was not that Poles were not interested in this type of film, but rather that time was needed to address this demand.

The huge appetite of Poles for cinema of this type can be deduced from the popularity of Polish contemporary literature, tackling male-female relations in a "light way", epitomized by the novels of Katarzyna Grochola (some of which eventually found their way onto screen), as well as of romantic comedies imported from the neighbouring Czech Republic, some of them based on the international bestsellers of Michael Viewegh, such as Román pro zeny (From Subway with Love, 2005) by Filip Renc. Eventually several Polish scriptwriters and directors started to specialize in romantic comedy. Among them are Piotr Wereśniak, Ryszard Zatorski and scriptwriting-directing duo, Andrzej Saramonowicz and Tomasz Konecki, as well as the previously mentioned veteran of Polish genre cinema, Juliusz Machulski. I chose Saramonowicz and Konecki's films, because their films best represent a new approach to cinema, pertaining to the new millennium and represent a specific type of romantic comedy, which renders it different from those coming from the Czech Republic.

Since the beginning of their collaboration in 2000, Saramonowicz and Konecki have produced several commercially successful films and television series. I focus here on two of them, Testosteron (Testosterone, 2007) and Lejdis (2008), because they best reflect a new, "holistic" approach to the promotion of films,

${ }^{10}$ E. Mazierska, Polish Postcommunist Cinema ...; Polskie kino popularne, eds. P. Zwierzchowski, D. Mazur, Bydgoszcz 2011; Popular Cinemas in East Central Europe, eds. D. Ostrowska, F. Pitassio, Z. Varga, London 2017.

${ }^{11}$ E. Ostrowska, op. cit. 
whose purpose is to maximize the film's audience. This includes the authors taking responsibility for the whole life cycle of the film, from its conception to distribution. To this end, Saramonowicz set up a production firm, Van Worden. Their films also had their own websites, controlled by the film's authors, which included information from the set, interviews with actors and, after the films' premiere, news about the films' successes. To that we should add their strong presence in the media, as measured by numerous interviews, given particularly by Saramonowicz, who appropriated the position of the main author of their films. Such a practice, although taken for granted in Hollywood, was a novelty in Poland, where films normally used to enter the viewers' imagination only after their release in cinemas. ${ }^{12}$ In interviews, the scriptwriter underscored the fact that their films are meant to offer entertainment; all other values have to be subordinated to this meta-value. By contrast, values pertaining to auteur cinema, such as conveying one's personal views and universal truths, were omitted from Saramonowicz's discourse. ${ }^{13}$

In common with the creators of Polish heritage cinema, who re-used wellknown literary material to add attractiveness to their films, Saramonowicz and Konecki also tried to capitalize on the popularity of their "hypotexts", although they were of a different character. Testosteron is based on a play written by Saramonowicz, which achieved commercial success in Polish theatres, and Lejdis was based on a website set up and run by a group of women who went by that name (a Polish colloquial phonetic spelling of the English word "ladies"). ${ }^{14}$ Although websites do not provide literary material of the same type as novels and plays and their popularity is of a different sort, the authors emphasized the fact that websites (as opposed to more lofty literary genres) offer more up-to-date access to social reality; for example, their language is more direct and colloquial, due to being written by "ordinary people". The fact that Saramonowicz, who is a scriptwriter, rather than Konecki, the director, is regarded as the most important member of the film production team, can also be attributed to the fact that his cultural capital was higher due to his earlier achievements as a writer. ${ }^{15}$

To increase the commercial value of the film, filmmakers employed two main strategies used in genre cinema at large and romantic comedy in particular. One consisted of using popular actors, such as Maciej Stuhr, Robert Więckiewicz and Piotr Adamczyk. Some of these actors, such as Adamczyk, played in both films. The second strategy was to set their films in the milieu of the Polish upper-middle class. Testosterone's mise-en-scène is that of a hotel in picturesque surroundings

${ }^{12}$ M. Olszowska, “Autor! Autor! O problemie autorstwa w polskim kinie popularnym na przykładzie filmów 'Lejdis' i ‘Testosteron' Tomasza Koneckiego oraz Andrzeja Saramonowicza”, [in:] Polskie kino popularne, eds. P. Zwierzchowski, D. Mazur, Bydgoszcz 2011, pp. 269-271.

13 A. Kyzioł, "Pakiet hormonalny", Polityka 2009, 29 January 2009, http://www.polityka.pl/tygodnikpolityka/kraj/278625,1,saramonowicz-andrzej-konecki-tomasz.read (accessed: 20.12.2015).

14 M. Olszowska, op. cit., p. 267.

15 Ibid., p. 266. 
where a wedding reception was meant to happen, but did not take place, because the wedding had been interrupted, not unlike in Four Weddings and a Funeral (1994) by Mike Newell. This choice of setting allowed the filmmakers to simultaneously achieve two objectives: to give the appearance of affluence, while saving on the budget for set design. Lejdis is set mostly in middle-class Warsaw apartments and one upper-class house, complete with a grand piano, gym and a modern-looking editorial office, publishing a women's magazine. This smooth cinematography enhances the impression of affluence. All the women in the film have middle-class jobs or do not work for a living and the husbands of two of them belong to Poland's economic and political elite. One of them is a millionaire businessman; another a European MP. But, irrespective of each of the character's job, money is not an issue, only love, or rather sex.

In Testosterone this is signalled by the very title of the film, which alludes to a vulgar version of Freudism, according to which men's behaviour is a consequence of the eponymous hormone. If allowed, men would have sex all the time. Culture is merely a veneer, hiding the sexual desire boiling under the surface. The story of Stavros, the oldest character in the film and the father of the groom whose wedding was violently interrupted, proves this point. We learn that all his life he had been travelling extensively thanks to working in the film industry, and in each new place he visited, he had an affair with a local girl. This led to him fathering many children, the majority of them out of wedlock. Stavros does not even know the identity of some of his offspring, as proved by the fact that the waiter serving him at the hotel turns out to be his own son. The father feels no remorse for his behaviour because, he argues, women also ultimately want sex, being "bitches", as the men call them throughout the film. This opinion is confirmed when the men are comparing stories of their affairs, which show that one man's girlfriend or wife was another man's lover. In this way, they are exonerated from any sense of guilt they might have due to their promiscuity.

By contrast, love, understood either as an unruly passion, as madness, or as companionship, based on mutual understanding and respect, is nowhere to be seen, because one woman can easily be replaced by another. Not surprisingly, women in Testosterone harbour no romantic illusions about men. The bride, who abandons the wedding, telling her groom that she does not love him, did so not because of being in love with another man, but because she used the wedding with its violent interruption as a publicity stunt, whose purpose was to draw media attention to her new record. The idea that love does not matter, only sex, is underscored by the language and gestures used by the characters, full of vulgarity. Not surprisingly, accusation of sexism of the lowest type was typical of the criticism directed at the film by reviewers. ${ }^{16}$ That said, the sexual exploits of the characters are presented

${ }^{16}$ A. Zuchora, "Testosteron", Film 3, 2007, pp. 33-36; J. Wróblewski, "Samcze sny”, Polityka 10, 2007, p. 67. 
only in retrospective or imaginary parts (as we are never sure whether what the men say is true or a fabrication meant to impress their interlocutors), suggesting that for men in Testosterone dirty talk is a substitute for actual sex.

I mentioned earlier that the interrupted wedding likens Testosterone to Four Weddings and a Funeral. As in Newell's film, in Konecki and Saramonowicz's movie we have another wedding; one that ends the film. Both films point to the unsuitability of the institution of a wedding to contemporary times. However, in Four Weddings and a Funeral the couple at the centre of the narrative does not get married, acknowledging that love can last without tying the knot. In Testosterone, the wedding goes ahead, pointing to the importance of tradition and keeping up appearances, despite a changing social reality. This might be seen as a reflection of the cultural differences between the two countries, where the respective weddings take place (or not). Britain is a more secular country than Poland, where Catholic values and traditions still inform the behaviour of the bulk of society.

Lejdis was meant to be a response to Testosterone by presenting the world from a female perspective and being addressed to women. It focuses on four women, the titular "lejdis" (ladies), who are childhood friends, living in the same apartment block. The women's sex lives are at the centre of the narrative, not unlike in Sex and the City (1998-2004), created by Darren Star, to which Saramonowicz and Konecki's film was compared. Again, I use the term "sex life" deliberately, because for the majority of the lejdis, sex and its consequences matter more than romance. The best example is Gośka, the wife of a European MP, who flies to Brussels every month in the hope that her husband will impregnate her. She tries to make their meetings romantic by bringing sexy underwear and burning candles, but ultimately this is a means to the goal of having a baby rather than enjoying each other's company. Another woman, nicknamed Korba, engages only in casual sex and avoids commitment on the ground that men eventually leave their long-term partners for their younger versions, and she does not want to risk finding herself in this position. Their cynical attitude to men is validated by the narrative, because the majority of men whom the lejdis encounter are not up to the task of being romantic lovers. Each woman in the end finds her "perfect" match, but this appears to be a result of the filmmakers adhering to the "happy ending" formula at all cost rather than a logical consequence of the narrative's development. Although romantic love matters in Lejdis more than in Testosterone, ultimately the film does not give much hope for its likelihood and even less for its longevity. While friendship between women appears to be eternal, love turns out to be flimsy or based on misconception.

The question arises: why are Polish romantic comedies so unromantic? I will point to two principal reasons. One is an undeveloped "culture of love" in Poland. As I wrote elsewhere, love used to be a neglected subject in Polish literature and postwar cinema. When it was tackled at all, it was typically in the context of its impossibility, resulting from the main character being called to fulfil his duty 
towards his country, such as fighting in a war or in an uprising, which required sacrificing private happiness to a higher cause. ${ }^{17}$

Moreover, in certain films, most importantly those of the Cinema of Moral Concern, flourishing in the second half of the 1970s, the conflict between an individual and the state was often displaced by the conflict between a man and a woman, with the woman paying the price for the man's professional failure and moral bankruptcy. This contrasts with the situation in Czech cinema, where romantic love had more narrative autonomy and was treated not as an obstacle, but as a means to achieve some goal important for the community, as in Ostre sledované vlaky (Closely Observed Trains, 1967) by Jiří Menzel, where the character fulfils a heroic deed after a night of lovemaking. Polish filmmakers thus have few positive models to follow, as far as their national culture is concerned.

The second reason why Testosterone and Lejdis are so poor in romantic love are the changes in attitudes to love, pertaining to Western society post-1960s and revealed in many romantic comedies produced in the United States from the 1970s onwards. Frank Krutnik, drawing on the work of such authors as Brian Henderson and Janet Maslin, describes a certain type of a romantic comedy flourishing in the 1970s and 1980s as "nervous romances", which "betray a wistful nostalgia for 'the whole romantic thing' while acknowledging its impossibility". ${ }^{18}$ Moreover, from the 1970s American cinema recognizes the autonomous value of sex, as opposed to being only a component of a happy relationship between a man and a woman. ${ }^{19}$ Some of the Western films and television series which inspired Saramonowicz and Konecki, such as Sex and the City reflect both tendencies. In them we find nostalgia for romance, particularly revealed by women, and an appreciation for sex for sex's sake. This leads, not unlike in Sex and the City, to the situation where sex and friendship are separated from each other. However, while in Western films recognition that love does not last leads to a downgrading of the institution of marriage, in Polish cinema marriage is still very important.

The two films discussed here did very well in the box office, with Testosterone having 1.7 million tickets sold and Lejdis - over 2.5 million tickets sold. ${ }^{20}$ This was explained by the great appetite of Polish viewers for romantic comedies and the small supply of Polish films to fulfil this appetite, hence little competition for Konecki and Saramonowicz, except for films imported from abroad. ${ }^{21}$ This opinion is supported by the fact that these films remained a provincial affair,

${ }^{17}$ E. Mazierska, Masculinities in Polish, Czech and Slovak Cinema: Black Peters and Men of Marble, Oxford 2008, pp. 133-136.

${ }^{18}$ F. Krutnik, "Love lies: Romantic fabrication in contemporary romantic comedy", [in:] Terms of Endearment: Hollywood Romantic Comedy of the 1980s and 1990s, eds. P.W. Evans, C. Deleyto, Edinburgh 1998, p. 19.

19 P.W. Evans, C. Deleyto, "Introduction: Surviving love", [in:] Terms of Endearment..., pp. 1-14.

20 A. Kyzioł, op. cit.

21 J. Wróblewski, op. cit. 
namely, did not travel outside Polish borders, not even to countries of the old Eastern Bloc, unlike Czech films, which did well both in Poland and even in the West.

\section{Popular artistic cinema: The case of Day of the Wacko}

While the work of Saramonowicz and Konecki fits the model of purely commercial cinema with few if any artistic pretensions, Marek Koterski's films adhere to the auteurist model. All of them cast as the main character a man similar to Koterski, who is often named Miauczyński. The represented reality is filtered by the main character's sensitivity, marked by a distaste for social reality, as well as self-hatred, which afford the film a surreal feel, verging on grotesque. Koterski's characters use an idiosyncratic language, a kind of intensification of the everyday language of ordinary Poles with its repetitions and vulgarisms. The language reflects not how Poles talk, but how Koterski's protagonist hears them talking as simpletons detached from the beautiful language of their Romantic ancestors. Moreover, Koterski's films always focus on the same set of problems, such as the suffocating character of a nuclear family and the low position of artists and intellectuals in postwar Poland.

Critics do not deny Koterski's originality or pandering to the mass taste. If anything, the long-time marginal status of this director is attributed to his nonconformity and a certain disregard of the audience, reflected in the fact that it is difficult to pigeonhole his films in terms of genre or film movements. At the same time, if we compare Koterski's films made under state socialism, such as Dom wariatów (The House of Nutters, 1985) and Życie wewnętrzne (Inner Life, 1987) to those made in postcommunist Poland, such as Ajlawju (1999) and Day of the Wacko, with the last being of special interest to me, then we notice that they underwent a transformation.

The main difference pertains to the use of humour. Although Day of the Wacko tackles serious issues, such as the place of the intelligentsia in postcommunist Poland, it is regarded as one of the funniest films made in Poland after 1989. Unlike Koterski's early films, where humour is subdued, idiosyncratic and very dark, in Day of the Wacko it is easier to grasp and lighter. Each episode is relatively short and when its comedy potential is exhausted, the film moves on to the next scene, usually set in a different place. This makes Day of the Wacko funnier than Koterski's earlier productions and affords it a dynamism which his earlier films lacked. To these qualities we should add its higher production value. Although Day of the Wacko is not a high-budget film, it differs from Koterski's earlier works by being a star-studded production, with leading actors employed even in minor parts. Moreover, it has a more versatile mise-en-scène than Koterski's remaining films. It includes scenes on the beach, in school, in a garden, in a sports stadium, on a street and in several apartments. Although the film is about the "wacko", 
locked in his private universe, it gives a sense of space and movement. Similarly, although the protagonist complains about his low economic status, his apartment and the interiors he visits come across as tasteful and bright. He is also more likeable than his earlier incarnations in The House of Nutters and Inner Life. It is possible to like him and identify with him. To that we shall add several moments, when Koterski demonstrates his visual imagination. I refer particularly to the episode at the sports stadium, where representatives of different political parties fight over the Polish banner, tearing it apart, metaphorically destroying Poland in their fight for power or when Miauczyński throws matches at the ceiling when complaining about the fate of an intellectual in Poland. Both scenes also deserve attention because of their soundtrack. The first includes a cacophony of sounds, bringing to mind a football match; the second provides a rhythm to the character's soliloquy, as if he was rapping.

For an arthouse film, Day of the Wacko was a box-office success, selling over 400,000 tickets in the cinemas. Thanks to this film, Koterski forged for himself a unique position in Poland of being a hero of both arthouse and mass audiences. Because of his talent to make popular arthouse films, as well as the choice of a neurotic character, Koterski can be compared to Woody Allen, whose films excellently fit the idea of popular arthouse cinema. Another filmmaker to whom Koterski can be compared is Jean-Pierre Jeunet, as his trajectory is similar to that of the French director, whose greatest success, Amelie (2001), came after making some darker films such as Delicatessen (dir. Jean-Pierre Jeunet, Marc Caro, 1991) and The City of Lost Children (La Cité des Enfants Perdus, dir. Jean-Pierre Jeunet, Marc Caro, 1995) and to a large extent was a result of choosing a more appealing protagonist. Adam Miauczyński in Day of the Wacko is not as cute as Jeunet's Amelie, but still likeable.

How did it happen that these two approaches, arthouse and mainstream, merged in Day of the Wacko? Koterski himself, when I asked him, insisted that Day of the Wacko is not different from his earlier productions. What might have changed is the audience, who matured to appreciate his films. This might in part be the case, as by the time he made Day of the Wacko Koterski had amassed a certain cultural capital, which eventually paid off. However, another factor is at least as important: the role of the film's producer. Unlike Koterski's early films, which were produced in the Irzykowski Studio, specializing in low-budget, experimental films, Ajlawju and Day of the Wacko were produced by Zebra, headed by the previously mentioned Juliusz Machulski. Machulski was also Day of the Wacko's executive producer. While Ajlawju was only a partial success due to pushing Koterski too strongly towards commercial cinema, in Day of the Wacko the personalities of the director and producer have merged perfectly. While the plot and character belong fully to Koterski, the film's dynamism, the lack of any moments which are not funny, the "brighter", more middle-class interiors and the 
greater use of exteriors can be attributed to Machulski's intervention, as well as to the higher budget that the director enjoyed on this occasion.

\section{Conclusion}

After the fall of state socialism, popular cinema gained in importance in Poland. This is reflected in the large production of genre films, such as gangster films, heritage films and romantic comedies, and the production of popular arthouse films. That said, genre films, such as those made by Saramonowicz and Konecki, are marked by a certain crudeness and regressive ideology, which puts off the more demanding section of viewers and prevents them from gaining international fame, even in countries of the old socialist bloc. At the same time, popular arthouse films are very rare, testifying to the great difficulty of making such films. In addition, when Polish cinema does achieve success abroad, it is largely thanks to making arthouse films, as demonstrated by the recent Oscar for Pawel Pawlikowski's Ida (2013). On the basis of that, one can at best be cautiously optimistic about the future of popular cinema in Poland.

\section{Bibliography}

\section{Secondary sources}

Adamczak M., Globalne Hollywood, filmowa Europa i polskie kino po 1989 roku. Przeobrażenia kultury audiowizualnej przełomu stuleci, słowo/ obraz terytoria, Gdańsk 2010.

Dyer R., Only Entertainment, 2nd ed., Routledge, London 2002.

Evans P.W., Deleyto C., "Introduction: Surviving love", [in:] Terms of Endearment: Hollywood Romantic Comedy of the 1980s and 1990s, eds. P.W. Evans, C. Deleyto, Edinburgh University Press, Edinburgh 1998, pp. 1-14.

Krutnik F., "Love lies: Romantic fabrication in contemporary romantic comedy", [in:] Terms of Endearment: Hollywood Romantic Comedy of the 1980s and 1990s, eds. P.W. Evans, C. Deleyto, Edinburgh University Press, Edinburgh 1998, pp. 15-36.

Mazierska E., Masculinities in Polish, Czech and Slovak Cinema: Black Peters and Men of Marble, Berghahn, Oxford 2008.

Mazierska E., Polish Postcommunist Cinema: From Pavement Level, Peter Lang, Oxford 2007.

Michałek B., "Wokół polskiego filmu o współczesności", [in:] Bolesław Michałek, ambasador polskiego kina: Wspomnienia i artykuty, ed. A. Helman, Rabid, Kraków 2002 [1962], pp. 119132.

Olszowska M., “Autor! Autor! O problemie autorstwa w polskim kinie popularnym na przykładzie filmów Lejdis i Testosteron Tomasza Koneckiego oraz Andrzeja Saramonowicza”, [in:] Polskie kino popularne, eds. P. Zwierzchowski, D. Mazur, Wydawnictwo Uniwersytetu Kazimierza Wielkiego, Bydgoszcz 2011, pp. 261-273.

Ostrowska E., The Power of Love: Polish Postcommunist Popular Cinema, forthcoming.

Polskie kino popularne, eds. P. Zwierzchowski, D. Mazur, Wydawnictwo Uniwersytetu Kazimierza Wielkiego, Bydgoszcz 2011. 
Popular Cinemas in East Central Europe, eds. D. Ostrowska, F. Pitassio, Z. Varga, I.B. Tauris, London 2017.

“Uchwała Sekretariatu KC w sprawie kinematografii”, [in:] Syndrom konformizmu: Kino polskie lat sześćdziesiatych, eds. T. Miczka, A. Madej, Katowice 1994, pp. 27-34.

Wróblewski J., "Samcze sny” Polityka 2007, no. 10, p. 67.

Zajiček E., Poza ekranem. Kinematografia Polska 1918-1991, Filmoteka Narodowa, Warszawa 1992.

Zuchora A., "Testosteron", Film 2007, no. 3, pp. 33-36.

\section{Online sources}

Kyzioł A., "Pakiet hormonalny", Polityka 29.01.2009, http://www.polityka.pl/tygodnikpolityka/ kraj/278625,1,saramonowicz-andrzej-konecki-tomasz.read (accessed: 20.12.2015).

\section{Filmography}

Ajlawju, dir. M. Koterski, Poland 1999.

Amelie, dir. J.-P. Jeunet, France-Germany 2001.

Connection, The, dir. S. Clarke, USA 1962.

Czlowiek z marmuru [Man of Marble], dir. A. Wajda, Poland 1977.

Człowiek z żelaza [Man of Iron], dir. A. Wajda, Poland 1981.

Delicatessen, dir. J.-P. Jeunet, M. Caro, France 1991.

Dom wariatów [The House of Nutters], dir. M. Koterski, Poland 1985.

Dwa żebra Adama [Adam's Two Ribs], dir. J. Morgenstern, Poland 1963.

Dzień świra [Day of the Wacko], dir. M. Koterski, Poland 2002.

Four Weddings and a Funeral, dir. M. Newell, UK 1994.

Ida, dir. P. Pawlikowski, Poland-Denmark-France-UK 2013.

Katyń, dir. A. Wajda, Poland 2007.

La Cité des Enfants Perdus [The City of Lost Children], dir. J.-P. Jeunet, M. Caro, France-Germany-Spain-Belgium 1995.

Lejdis [Ladies], dir. T. Konecki, Poland 2008.

Lekarstwo na miłość [Medicine for Love], dir. J. Batory, Poland 1965.

Matżeństwo z rozsądku [Marriage of Convenience], dir. S. Bareja, Poland 1966.

Ostře sledované vlaky [Closely Observed Trains], dir. J. Menzel, Czechoslovakia 1967.

Popiót i diament [Ashes and Diamonds], dir. A. Wajda, Poland 1958.

Román pro zeny [From Subway with Love], dir. F. Renc, Czech Republic 2005.

Seksmisja [Sex Mission], dir. J. Machulski, Poland 1984.

Testosteron [Testosterone], dir. T. Konecki, A. Saramonowicz, Poland 2007.

Vabank, dir. J. Machulski, Poland 1981.

Życie wewnętrzne [Inner Life], dir. M. Koterski, Poland 1987.

\section{TV Series}

Sex and the City, created by D. Star, USA 1998-2004. 


\title{
No longer a trivial entertainment: Popular cinema in Poland after 2000
}

\begin{abstract}
Summary
This article discusses two types of popular films produced in Poland after 2000, a subgenre of romantic comedy, which I label "sexual comedy", represented by the films of Andrzej Saramonowicz and Tomasz Konecki, and "popular arthouse film”, represented by Dzień świra (Day of the Wacko, 2002) by Marek Koterski. To understand the specificity of Polish popular cinema in this period, the author locates it in the postwar history of filmmaking in this country, arguing that making popular films was met in this country with great resistance. The situation has changed after the fall of state socialism, when cinema had to be more receptive to the audience's demands. The films discussed in this article reflect both this pressure and the difficulties involved in making such films.
\end{abstract}

